suggests that success in this field has to some extent made co-operation more difficult in the political field.

This aspect of co-operation, overshadowed as it may be by political questions at the moment, cannot be dismissed so cavalierly. Others besides the scientific worker may be disposed to inquire why a like approach should not be possible to all those difficult problems in the political field which threaten the peace of the world at the moment, and Sir Alfred himself has indicated some of the factors involved in such an approach. No means of promoting the quantity or technique of international co-operation can be neglected. Both alike increase the probability that the existing organisation for co-operation such as the League provides will be used. Equally the study of the technique of co-operation not merely supplies warning of the defects or dangers of existing organisation for co. operation but also assists in the modification or development of that organisation to meet changed conditions. Sir Alfred's conclusions in fact underline this necessity for a continually developing organisation for international co-operation, both to provide the machinery for settling disputes, and also to assist its members in discovering sensible ways of dealing with their own affairs.

Both books can be heartily welcomed as assisting the reader to arrive at that impartial and accurate knowledge of the functions and achievements of the League upon which alone its authority is finally based, and without which we can scarcely hope for that new spirit in the whole field of international politics which is the central problem of the League.

\section{R. Brightman.}

\title{
Principles of Genetics
}

\section{Genetics}

By Prof. H. S. Jennings. Pp. 351. (London : Faber and Faber, Ltd., 1935.) 15s. net.

$\mathrm{T}$ HE extraordinary growth of genetics as a science has been accompanied by the publication of innumerable volumes giving general accounts of progress or more detailed studies of particular fields. The contributions of Prof. Jennings to this subject have been notable, especially his work on the Protozoa and on the mathematical rules of segregation. His writings, moreover, bear the hall-mark of clarity and orderliness of thought. They are therefore well adapted for the introduction of these aspects of biology to the general reader. Another notable aspect of Prof. Jennings's books is that he does not confine his biological conclusions to animals and plants, but brings them home directly by their application to man himself. The present volume will sustain his reputation as a thinker who faces the biological and eugenic conclusions to be drawn from genetical research.

This volume is a presentation of the general features of genetics such as every educated person should know. It is not intended as a technical introduction, but it points out and enlarges upon those aspects of the subject which the intelligent layman will wish to understand. The first chapter deals with the hereditary material, the chromosomes, which are passed on from cell to cell and from generation to generation. In Chapter ii this "genetic system" is considered in contrast with the muscular or the nervous system. The picture of meiosis given at this stage is obviously incomplete, corresponding with knowledge about twentyfive years ago. But the author in his treatment follows the history of the development of know. ledge, the more recent phenomena of linkage and crossing-over being considered in Chapter vi under the constitution of the chromosomes.

Sex-linked inheritance is explained, first from the well-known cases of hæmophilia and colour blindness in man, and afterwards from the phenomena in Drosophila. "The relation of genes to characteristics" considers multiple, duplicate and modifying factors in Drosophila and the action of genes in development, but it ends characteristically with a study of physical and mental inheritance in identical human twins, which is continued in the next chapter on the "relation of characteristics to the environment", where the facts are set forth clearly and without bias. The last two chapters, on genetic variations, refer to mutations in many organisms and the methods by which they originate.

In a work of this kind, where choice of topics is essential, there are many which might have been included, but the author wisely emphasises principles rather than facts, and the book can be recommended to every reader who wishes to have an understanding of genetics in its biological aspects and relations rather than a detailed treatise on the subject. Among slips noted is the statement (p. 169) that the garden pea and the sweet pea have eight chromosomes.

\section{R. RUgGles Gates.}

